\title{
PRICING POLICIES IN GOVERNMENT CONTRACTS
}

\author{
Ralph C. Nash, JR.*
}

\section{INTRODUCTION}

The federal government is the largest purchaser of goods and services in the nation. In this capacity, the government buys all types of items from pencils to spacecraft. However, the bulk of the money spent by the government is for custom-made goods or specialized services which are furnished to meet specific requirements of the various agencies. In this type purchasing, the pricing of goods and services cannot be arrived at by normal techniques in a market where sellers manufacture goods for anticipated demand. There the seller establishes the price based on competitive conditions and the buyer buys at his option. However, there is little bargaining over price. In the pricing of custom-made goods, on the other hand, the buyer becomes much more intimately involved in the determination of price. It is this position in which the federal government has found itself to a greater and greater extent in the past few years. ${ }^{2}$ As this has occurred, the government has discussed and promulgated a substantial amount of policy governing the participation of government procurement personnel in the pricing of the goods and services it buys. The purpose of this article is to analyze the techniques that are being used, the changes that have been made in this area in the past few years, and some of the possible results of the current pricing policies.

In the past three years the Department of Defense, by far the largest purchaser in the government, has undertaken a major program of reviewing its pricing techniques and of revising them to accomplish new purposes. As a result of this effort, the Department of Defense has issued several important changes of policy and numerous statements clarifying its intent in changing the policy. This information contains the clearest statement of what the problems of the government are in this area and what current actions are being taken to solve these problems. This article will therefore deal primarily with these Department of Defense policies, since they represent the most significant effort to resolve the problems in pricing. It should be understood, however, that the other government agencies with major procurement

*A.B. 1953, Princeton University; J.D. 1957, George Washington University. Associate Professor and Director of the Government Contracts Program, George Washington University.

${ }^{I}$ Government procurement totals approximately $\$ 35$ billion annually at the present time. This figure is difficult to identify precisely but it is in this range. The major component of this total is the Department of Defense, where the total procurement figure was $\$ 27.8$ billion in fiscal year 1962 , Subcommittee on Defense Procurement of the Joint Economic Committee, Background Material on Economic Aspects of Military Procurement and Supply, 88th Cong., Ist Sess. 7 (1963). Non-defense purchases bring the figure up to the $\$ 35$ billion range.

2For an interesting analysis of the portion of government procurement dealing with major systems, see M. J. Peck \& F. M. Scherer, The Weapons Acquisition Process cc. 2 through 7 (1962). 
programs face the same problems and in many cases are using similar techniques to solve their problems.

\section{The UsE of Competitron}

In a situation where prices are established by sellers unilaterally, the role of competition is to offer buyers reasonable alternatives to a seller's product and hence to assure reasonable prices. This type of competition operates in only a small portion of government procurement. However, there is still a major effort to utilize competition in establishing prices in government procurement. The technique used is to solicit competitive bids or proposals to a specification furnished by the government and to select the best bid or proposal for the award of the contract. If the specifications can be made so definitive that all aspects of the work are clearly spelled out, advertised procurement techniques are used and the award is made with price as the major deciding factor. ${ }^{3}$ On the other hand, if there are other aspects of the work which must be evaluated and the specifications cannot be made completely firm, competitive negotiation is undertaken with the government making its judgment on the basis of all material factors and reserving the right to negotiate further with the contractors after the proposals are received. 4 In either case, there is the underlying presumption that the use of competition is the most effective pricing technique since it will prevent contractors from inflating their prices to include an amount of profit which is unreasonable.

Thus, competition can be looked at as the preferred technique for contract pricing -the technique which is most like the operation of the commercial market technique where all prices are established with a knowledge of market conditions. The difficulty in this type of competition lies in the need for specifications to define the government requirement. If the specifications are not relatively precise, the con-

${ }^{8}$ The procurement statutes specify advertised procurement as the preferred method of procurement. Io U.S.C. $\$ 2304$ (a) (1948), as amended by Pub. L. 87-653, Sept. 10, 1962, 41 U.S.C. $\$ 252$ (c) (1949). It should be noted that the 1962 amendment to ro U.S.C. $\$ 2304(a)$ was intended to express the congressional policy favoring advertised procurement in more specific terms. The new language states: "Purchases of and contracts for property or services covered by this chapter shall be made by formal advertising in all cases in which the use of such method is feasible and practicable under the existing conditions and circumstances. If use of such method is not feasible and practicable, the head of an agency, subject to the requirements for determinations and findings in section 23I0, may negotiate such a purchase or contract, if ...." The Department of Defense (DOD) has identified four prerequisites for using the formal advertised method. These are: (I) a complete, adequate, and realistic specification, ( 2 ) two or more suppliers available, willing and able to compete effectively, (3) circumstances permitting the selection of the successful bidder to be made on the basis of price alone, and (4) sufficient time to carry out the administrative procedures necessary for formal advertising. Hearings Before the Procurement Subcommittee of the Senate Committee on Armed Services [hereinafter cited as Procurement Study], 86th Cong., 2d Scss., pt. $I$, at 67 (1960).

'The fact that competition can and does occur in negotiated procurements has been difficult to get across to Congress. However, in fiscal year I $96 \mathrm{x}$ Department of Defense statistics indicate that $32.9 \%$ of all procurement was based on price competition (including approximately $13 \%$ comprising formal advertising). In fiscal year 1962 this was raised to $35.6 \%$. The DOD goal is $40 \%$ of procurement using price competition. See Morris, Better Performance and Control of Costs in Defense Contracting, Government Contracts and Procurement (Commerce Clearing House, 1963). 
tractors will not be able to estimate their costs accurately with the result that the prices submitted may be far from accurate. In such cases, the primary benefits of competition in contract pricing are not fulfilled since the lack of accuracy in the estimates may result in prices which are either loaded with contingencies or too low. In either case the parties to the contract have agreed to a price that will create difficulties during performance.

The critical problem, then, is to obtain good specifications on which competitive procurement can be based. In some cases the government is capable of preparing such specifications with its own personnel, but in the majority of cases, this job of preparing specifications falls upon contractors and requires a large amount of preliminary research and engineering before the actual writing of the specifications can be undertaken. ${ }^{5}$ Hence, a major portion of the procurement effort of the Department of Defense is aimed at procuring the preparation of the specifications for needed products and the problem becomes one of the best pricing technique for buying these development contract services. Here too competition is one answer to the problem but it must be realized that such competition is related to factors such as technical competence, managerial ability and background in a particular field more than price. Thus, the further removed the program is from manufacture of a product, normally the less of a factor is price competition.

An additional difficulty arises when the specification preparation is done by a contractor. In such cases, the development contractor usually is in a preferred position when the initial manufacturing work is required. ${ }^{b}$ This preferred position is a result of the fact that the specifications are written with the contractor's manufacturing facilities in mind, he has already obtained special tooling to produce prototypes, the specifications contain requirements which can only be met using information that is proprietary to the contractor or the lead time is so short that no other contractor can assimilate the information in the specifications in time to meet the delivery schedule. Usually in complex products, all or most of these factors are present. Thus, when the Government has finally reached the position where it has the necessary specifications to obtain competition, it finds that many other factors prevent the use of competition. Hence, one of the major areas of consideration in developing new procurement techniques is this need to prevent the development contractor from establishing this type of preferred position in all future manufacturing of the product.

Several steps have been taken in this direction in recent years. A major effort has been made to "break out" parts of a product for competitive procurement even

\footnotetext{
TThe government uses three general types of contract specifications: ( $x$ ) detail specifications, (2) performance specifications and (3) purchase descriptions. See Procurement Study, supra note 3, at 73-75; ASPR sec. 1, part 12 . When using the latter two types, however, the government has merely transferred the specification problem to the contractor-he must create a detail specification before the product can be manufactured. Often such procurements are made when several contractors already have such specifications available-when several products will meet the government's requirements and the contract specification is used merely to state that requirement in a general way.

${ }^{\circ} \mathrm{Sec}$ ASPR 3-108, 32 C.F.R. \$3.108 (1963).
} 
though the entire product would not be subject to competitive procurement.7 Hence, spare parts might be broken out or a component of a system might be susceptive to "break out." Occasionally an entire product can be established for competitive procurement in the third or fourth year of manufacturing. ${ }^{8}$ By this time the specifications may have become quite firm and there may be sufficient lead time to enable a second contractor to do the necessary preliminary engineering and tooling. In such cases, the government has some additional protection since it can always fall back on the first contractor if the second source fails. This type of effort usually seems to have the beneficial effect of forcing the first contractor to review his costs and reduce his prices so that the cost reduction benefits of competition are often carried through the balance of the manufacturing effort by such a technique. Another effort that has been undertaken in the past five years is to prevent development contractors from including components which are subject to proprietary rights in their designs. ${ }^{9}$ This is accomplished by requirements that such components be approved by the contracting officer prior to incorporation in the design or requirements that all such proprietary data be turned over to the government as part of the development contract. All of these policies are aimed at obtaining more competition.

All of these actions indicate that the Department of Defense is committed to the proposition that competition is the best method for establishing fair prices. To a large extent this view is a product of the idea, long held by the General Accounting Office and Congress, that government personnel cannot establish fair prices by cost analysis and hence must rely on competition. This extreme reliance on competition as a pricing mechanism is highlighted by the recent change to the regulations which incorporated a provision stating that government personnel should make no effort to reduce prices of the low proposer in negotiated procurements when adequate price competition has been obtained. ${ }^{10}$ Thus, the concept that competition is the best pricing technique seems firmly entrenched in government procurement.

${ }^{7}$ See the testimony of Secretary of Defense McNamara on March 28, 1963 before the Subcommittec on Defense Procurement of the Joint Economic Committee, 88th Cong., Ist Sess. (1963) reprinted in Background Material on Economic Aspects of Military Procturement and Supply, stupra note I, at 69. In this testimony Mr. McNamara indicated that the initial effort in this new procedure was in the acro. nautical spare parts where competition was increased $78 \%$ in fiscal year 1962 . See also DOD Policy Paper set forth in Air Force Procurement Circular No. 90, Nov. 6, I963, 6 Gov't ConT. Rep. 980,135 (1963).

${ }^{8}$ Secretary MeNamara's first annual progress report on the DOD Cost Reduction Program [hercinafter cited as COST REDUCTION REPORT] indicates that 58 major procurements were made competitively (in lieu of the previous sole source method) during the third quarter of fiscal year 1963. He further indicates that this is a major aspect of the Cost Reduction Program. This report is Appendix 2 to the Report of the Subcommittee on Defense Procurement to the Joint Economic Committee, 88th Cong., Ist Sess. (July 1963 ).

A related effort is assuring that contractors promptly submit all data called for by devclopment contracts. (Until the data is submitted, the procuring agency is clearly unable to obtain competition.) For this purpose, a clause providing for withholding of $10 \%$ of the contract price until satisfactory data was delivered was added to the ASPR in April 1962. See ASPR 9-207.2, 32 C.F.R. $\$ 9.207-2$ (1962).

${ }^{10}$ ASPR 3-808.r(c), 32 C.F.R. $\$ 3.808 . \mathrm{I}$ (c) ( 1963 ). See also the DOD Policy Paper, supra note 7, stating that the reason for lower prices in competitive procurements is that they demand and get "a degree of industrial efficiency, economy and elimination of frills that normally cannot be imposed in the negotiation of noncompetitive contracts." 


\section{Noncompetitrue Pricing Techniques}

When price competition cannot be obtained, the government normally falls back on cost and profit analysis and negotiation to determine a fair price. ${ }^{11}$ This technique involved a detailed analysis of the estimated cost of performance of a job, the negotiation of this estimated cost, and the addition to such cost of a profit which the parties believe to be a fair reward for the work under contract. Hence, the determination of the price is handled as a two step procedure with the major emphasis placed on cost negotiation. In addition, since the government is usually unsure of its ability to accurately estimate the cost, the normal rule is to use a type of contract which delays the final establishment of the price to be paid until all of the costs have been incurred. In such cases, the costs paid are the "actual" costs of performance (excluding disallowed costs) ${ }^{12}$ and the profit paid is usually based on a predetermined arrangement established early in the performance of the work. The most frequently used types of contracts of this nature are the cost-plus-fixed-fee, cost-plus-incentive-fee, and fixed-price-incentive contract. ${ }^{13}$

This method of pricing contracts after the work has been completed is used by the government primarily to reduce the risk that the initial cost estimate is too high and thus that the government will pay too much profit. However, the immediate impact of the technique is to greatly reduce the incentive to the contractor to utilize resources efficiently in the performance of the job. Since costs will be reimbursed, the contractor need not treat costs in the same manner he would under a firm fixed price contract-where each expenditure of costs is looked at as an expenditure out of profit. Thus, the government is faced with a dilemma-if it could estimate costs accurately, it would use a firm fixed price contract and provide maximum incentive for the efficient use of resources, but since cost estimates are suspect, the government wants to reimburse only actual costs which destroys the incentive to reduce costs.

In an attempt to arrive at the best solution to this dilemma, the Department of Defense embarked on a program in March 1962, aimed at reducing the use of cost-plus-fixed-fee (CPFF) contracts. At the time this program was undertaken,

${ }^{11}$ ASPR 3-807.2, 32 C.F.R. $\$ 3.807 .2$ (I963) states: "Some form of price or cost analysis should be made in connection with every negotiated procurement action. The presence of adequate price competition, however, limits considerably the degree of analysis required. Cost data should not be requested when the contracting officer anticipates that there will be adequate price competition. However, if he determines, after proposals have been submitted, that there is not, in fact, adequate price competition, cost data may then be requested unless there are other bases (e.g., pricing data) available for evaluating the reasonableness of the quoted price." The DOD Policy Paper, supra note 7 , contains more detailed guidance on the proper use of cost analysis.

${ }_{12}$ The elaborate principles for determining "allowable" costs are set forth in section I5 of the ASPR and FPR.

${ }_{13}$ The major distinction between these types of contract is in the arrangement for determining the profit to be paid (they all reimburse allowable costs of actual performance with the exception of the fixed price incentive contract in the rare cases when the ceiling price prevents recovery of full costs). In the cost plus fixed fee contract, as the name implies, the fee to be paid is fixed at the beginning of the work. In the incentive types of contract the profit or fee varies inversely with the cost in accordance with a formula stated in the contract. See section 3, part 4, of ASPR and FPR. 
almost forty per cent of Department of Defense funds were being utilized on CPFF contracts and there was a general feeling that a sizable portion of this money was being spent inefficiently. ${ }^{14}$ Hence, the Armed Services Procurement Regulation was rewritten to require that incentive and fixed price contracts be used more frequently with quite stringent restrictions on the use of the CPFF type contract. ${ }^{16}$ In addition, the Department of Defense established goals for each service limiting the use of CPFF contracts to a specified percentage of their total funds. ${ }^{16}$ The result of this program has been a marked reduction in the use of CPFF contracts with a commensurate rise in the use of firm fixed-price, fixed-price-incentive and cost-plusincentive-fee contracts.

The use of incentive contracts in lieu of CPFF contracts theoretically should have two effects on contract prices. First, by itself the use of incentive contracts should increase the original cost estimates of contractors. ${ }^{17}$ This is almost inevitable since there is a much greater risk (of losing profits) on the incentive contract and therefore a much greater need for careful and realistic preparation of cost estimates. Stated another way, the incentive contract places a greater penalty on the contractor who "buys in" on a procurement by intentionally submitting a low estimate. Hence, the first result of this trend away from CPFF contracts should be higher estimated prices. Second, the use of incentive contracts will presumably result in reduced costs of performance of the work. The essence of this type of contract is a simple proposition by the government to the contractor-if you will reduce your costs we will pay you higher profits. Conversely, of course, the contractor that does not reduce his performance costs will be penalized by reduced profits. This inverse relationship between costs and profit is basic to the incentive contract. ${ }^{18}$

The most frequent criticism of this policy of using incentive contracts is the one that has been made by General Accounting Office and congressional commentators for a number of years-if the original target is too high, the incentive

\footnotetext{
14 This program is explained in Cost Reduction Report, op. cit. supra note 8, at 43. This report states that in the first nine months of fiscal year $196138.0 \%$ of DOD procurement funds were awarded on cost-plus-fixed-fee contracts whereas the percentage had declined to $2 x .1 \%$ in the first ten months of fiscal year 1963. For a more complete explanation of incentive contracting see RALPH C. NASH, JR., INCentive Contracting (Government Contracts Monograph No. 7, George Washington University, 1963).

${ }^{15}$ Revision 8 of the 1960 edition of ASPR (March 15, 1962) containing a complete revision of section 3, part 4 .

${ }^{18}$ The overall goals for maximum use of cost-plus-fixed-fee contracts are: Fiscal year $1963,25.8 \%$; Fiscal year 1964, x9.1\%; Fiscal year 1965, x2.3\%. Cost Reduction REPORT, op. cit. stipra note 8.

${ }^{17}$ One of the original reasons for increasing the use of incentive contracts was to force contractors to submit better cost and delivery estimates when original proposals were being submitted on new programs. More accurate estimates were vital to the Department of Defense because the information submitted by contractors was being used to make management decisions within the Department.

${ }^{13}$ The Department of Defense has taken two other steps that aim at this same goal of encouraging more efficient performance. One is the creation of a contractor performance rating system which will numerically rate all contractors performing major development contracts. These ratings will be used in future source selection decisions and in establishing profit rates on future contracts. See Department of Defense Directive No. $5 \times 26.38$ (Aug. $I, 1963$ ). A second step is the inclusion of past performance as a factor in the new profit formula. This will give contractors with good past performance a higher rate of profit on new contracts than that given contractors with poor past performance. See ASPR 3-808.5(d), 32 C.F.R. $\$ 3.808-5$ (d) (1963).
} 
profits paid may be primarily a result of this high estimate rather than cost reduction during performance of the work. ${ }^{19}$ This result of "unearned" profit is not as great on an incentive contract as it is on a firm fixed price contract because the contractor gets only a share of the reduced costs on the incentive contract whereas he gets the entire reduction on the fixed price contract. But the result does occur. It is a product of the fact that to create incentive, the government must take a riskthe risk of high original cost estimates. On the other hand, if the target cost is too low, the contractor will be penalized under the incentive contract. Hence, the need for better techniques for estimating costs is critical to the entire incentive contracting policy.

Why do cost estimates tend to be relatively inaccurate in some cases? One major reason is the fact that often the specifications for the work are not definitive. A second reason is that frequently the work has never been done before with the result that there is no prior cost experience available. Finally, there is the fact that cost estimates are by their very nature only accurate within certain limits since they are based on forecasts of future events. In some cases little can be done to overcome these difficulties but there are many instances where better procurement planning and management will help to minimize these causes for inaccuracy. One effort toward this end is under way in the Department of Defense at this time. This is the Project Definition Phase of major research and development programs. ${ }^{20}$ This effort is being inserted between the research phase and the development phase of such programs. It is a short (four to six months) effort to define the specifications, evaluate the critical aspects of the job, and improve the cost estimates for the development phase of the work which is to follow. In effect, it is a forced period of planning inserted into the program prior to the commencement of development work where large expenditures of funds will occur. Hence, it is specifically directed toward the problem of obtaining better target cost estimates in incentive contracts.

One other step which the Department of Defense has taken to improve its pricing practices in the area of costs is to increase the audit surveillance of contractors' proposals and the audit assistance furnished to contracting officers during negotiation of costs. ${ }^{21}$ In addition, the cost estimating personnel in the government

${ }^{10}$ See the testimony of the Comptroller General during Hearings Before the Procurement Subcommittee of the Senate Armed Services Committee, 86th Cong., 2d Sess. 146 (1960), and Hearings Before the Special Subcommittee on Procurement Practices of the Department of Defense of the House Armed Services Committee, 86th Cong., 2d Sess. 404 (1960). This attitude on the part of Congress is expressed in H.R. REP. No. I959, 86th Cong., 2d Sess. 28-33 (I960). Although there is a valid point to this type of criticism, it should not be overlooked that even if the incentive targets are inflated, the contract still gives incentive for cost reduction and thus still provides the motivation for efficient use of resources.

So Rubel, $R$ \& $D$ Contracts: Policies and Problems, in Research and Development Contracting, 25 (George Washington University, I963).

${ }^{21}$ Talk by Frank S. Howell, Ass't Auditor General of the Air Force, at the Federal Bar Association Conference on the Fiscal Aspects of Government Contracts, December 5-6, 1963. Mr. Howell commented that the general coneept that a Government auditor deals only with incurred costs is much too narrow. He pointed out that a substantial amount of the effort of the audit services of DOD at the present time is being spent in reviewing contractor's estimates of future costs (for pricing purposes) and that this was a proper function of the auditor. 
appear to be improving in their capabilities. However, with all of the improvements that have been made, it is clear that much can still be done to increase the ability of the government to evaluate and negotiate cost estimates of contractors on work which is being done for the first time. For instance, there is a great need for improved statistical pricing data in many of the product areas where the government buys (data similar to the learning curve data developed in the airplane industry). This is not a hopeless task but there is no doubt that much improvement is needed within the government before there can be an assurance that incentive contract targets are established with reasonable accuracy.

Another aspect of the determination of estimated costs is the problem of disallowed costs. It has been the policy of the government to disallow certain costs under cost reimbursement contracts in order to achieve uniformity of treatment of such costs by removing the need for individual consideration of their merits on a case-by-case basis. Such disallowed costs include entertainment, donations, certain advertising and recruitment expenses, interest and financing costs, as well as many other costs. ${ }^{22}$ These same criteria for the allowability of a cost are also being applied during the negotiation of estimated costs of fixed price or incentive contracts $^{23}$ and there appears to be a trend in the direction of increasing such disallowances. To the extent that such costs can be avoided during contract performance, this is a technique for encouraging the contractor not to incur the costs. However, to the extent these costs are necessary business costs, nonallowance of these costs is merely a profit reduction device. ${ }^{24}$ Hence, every contractor must discount the negotiated profit on a contract by some amount to reflect these unallowable costs. If the number of disallowed costs are increasing, this will become an increasingly serious problem in terms of negotiating contract prices.

A further difficulty that is present in the costing area is the treatment of so-called "contingencies." These are the costs which cannot be positively identified as a cost of performance yet may occur with varying degrees of probability. To a large extent they are a product of the view of the parties to the work-the government normally taking a relatively optimistic view and the contractor being somewhat more pessimistic. In a contract for work where there is no previous cost experience, of course, the "contingencies" can be expected to be sizable. Hence, the amount of contingencies included in the estimated or target cost will be of great importance in determining the accuracy of the estimate. The regulations provide for the inclusion of contingencies in estimates of cost if they "arise from presently known

\footnotetext{
${ }^{22}$ Section I5, part 2 of ASPR and FPR. The Bureau of the Budget will issue government-wide cost principles for industrial contractors in the near future.

${ }_{23}$ ASPR I5-603 (a), 32 C.F.R. $\$ 15.603$ (a) (1963) provides that when costs are being considered in' the negotiation of fixed-price type contracts the cost principles "shall be used as a guide" in evaluating cost data.

"Mr. Graeme Bannerman, Deputy Assistant Secretary of Defense (Procurement) has stated that many companies figure that such disallowances run from 2 to $4 \%$ of total costs. Hearings on Systems Development and Management Before a Subcommittee of the House Committee on Government Operations, 87th Cong., 2d Sess. pt. 2, at 553 (1962).
} 
and existing conditions, the effects of which are foreseeable within reasonable limits of accuracy."25 Thus, some contingencies can be included although the types allowed are difficult to define. In addition, in discussing firm fixed-price contracts the regulations state that such contracts can be used when the uncertainties in contract performance can be identified and their costs estimated with reasonable accuracy and "the contractor is willing to accept a firm fixed price at a level which represents assumption of a reasonable proportion of the risks involved." ${ }^{26}$ This statement implies that the government will also assume a reasonable proportion of the risks (contingencies) by including them in the contract price. Hence, this too is a statement that some contingencies may be included in cost estimates. However, in practice contracting officers are reluctant to include many contingencies in cost targets with the result that often these targets are closely priced.

Thus, the need to include more incentives for efficient use of resources in contracts has created a need for better cost estimating techniques to establish valid target costs in such contracts. Some efforts have been made by the government in this direction but much remains to be accomplished. The natural alternative in this situation, and the one that has been utilized by the Department of Defense, is to attempt to bring competition into play in establishing target costs on such contracts. This attempt is obviously difficult since the procurements in question are, by definition, those which cannot be made on the basis of price competition alone. In most cases they are procurements for development work or for manufacturing of major weapons systems where it would not be practical to bring in another contractor. In the latter case there is no method of obtaining competition once the weapons system is designed, ${ }^{27}$ but in the case of development work it is the practice of the Department of Defense to obtain competition. ${ }^{28}$ This competition, of course, is based on many factors in addition to price-factors such as past experience, technical ability, and management ability. However, the price aspect is considered and may play an important role in the selection of the contractor. In any event, the fact that there is competition, with one of the factors being price, results in contractors being very careful in evaluating their cost estimates and thus serves the purpose of achieving reasonable target costs. The danger in such a practice is that it will result in target costs that are too low-that in major development programs

${ }^{26}$ ASPR 15-205.7(c), 32 C.F.R. $\$ 15.205-7$ (c) (1963).

${ }^{36}$ ASPR 3-404.2(b), 32 C.F.R. $\$ 3.404-2$ (b) (1963). (Emphasis added.)

${ }^{27} \mathrm{~A}$ technique for utilizing competition to establish prices in this area is to tie the manufacturing to the design and obtain competition on the entire package. This can be done on smaller systems and components and it is being attempted on a few major systems through the use of fixed price options for manufacturing which are included in the development contract. See NASH, op. cit. supra note I4, at IOI-04.

${ }^{28}$ ASPR 3-403(c) discusses the techniques for buying development. It tells the contracting officer to make Government objectives known to all contractors and to request proposals including firm targets from contractors. It then continues, "performance and schedule completion targets proposed by each prospective contractor in meeting the Government's desired objectives, together with the estimated cost thereof, should be considered by the Government in the competitive contractor selection process." (Emphasis added.) This clearly contemplates the use of competition in development procurements. 
whose costs are not subject to accurate estimation, the extreme competitive pressure may induce contractors to underestimate their costs in an attempt to win the award. This is clearly a real possibility under a cost-plus-incentive-fee contract where the costs incurred by the contractor will be reimbursed in any event (subject to a reduction in profit for cost overruns). Thus, while competition can be used as a pricing device to a limited degree when prices are being established by cost evaluation, it should be recognized that such a practice may also cast some doubts on the validity of the cost estimate.

Turning to the determination of profits in the noncompetitive pricing situation, the tendency in government contracting in the past few years has been for profit levels to become quite uniform depending on the type of contract being used. Hence, profit rates on cost reimbursement contraçts were "negotiated" at five to seven per cent of estimated cost, rates on fixed-price incentive contracts fell between eight and one half and ten per cent, and rates on firm fixed-price contracts were normally set from ten to twelve per cent. ${ }^{20}$ There was little perceptible correlation between profit rates and past performance by the contractor or difficulty of the work being placed under contract. Neither was there much relationship between profit rates and the investment which the contractor was making in the job. For these reasons, the Department of Defense felt that new, more precise profit guidelines were necessary to make the profit component of government contract prices better serve the purpose of encouraging better performance by contractors and penalizing poor performance.

In addition, the earned profit rates on defense contracts appear to have continually decreased in the past few years. ${ }^{30}$ As this decrease has occurred, government officials

${ }^{29}$ See Study of Profit or Fee Policy, submitted to the Department of Defense by Logistics Management Institute, at 47-48 (rg62). This study was the basis for the new DOD weighted guideline profit policy. The study found that there was great reliance by negotiating personnel in the Department of Defense on historical profit levels.

${ }^{80}$ The Annual Reports to Congress submitted by the Renegotiation Board give total profits earned on renegotiable and non-renegotiable business reported by companies subject to renegotiation. These figures reflect the profits on business reported during the fiscal year before renegotiation has taken place. The trend is as follows:

Fiscal Year
1956
1957
1958
1959
1960
1961
1962
1963

Renegotiable Profits
$6.36 \%$
$5.72 \%$
$4.83 \%$
$4.21 \%$
$4.01 \%$
$3.62 \%$
$3.13 \%$
$2.94 \%$

Non-renegotiable Profits
$9.1 \%$
$10.1 \%$
$9.7 \%$
$7.9 \%$
$9.0 \%$
$7.8 \%$
information not available in
Renegotiation Board Reports

It should be noted that the trend indicated by these figures reflects the impact of all variables affecting the renegotiation process (one of which probably is the ability of the government in negotiating or setting the price). Two other variables which may have had a significant effect on the statistics are (a) the changed provisions governing the inclusion of standard commercial articles, 50 U.S.C. App. $\$ 1216(\mathrm{c})$ (1958); and (b) the new depreciation provisions included in the Revenue Act of 1962, INT. REv. CODE or $1954, \$ 46$, 76 Stat. 962 (1962), and Revenue Procedure 62-2I (July, 1962). The standard commercial article provision seemingly removed a substantial amount of sales from the renegotiation figures starting in 1958 (\$I 
have been forced to ask whether the profit rates on defense contracting were becoming so low that they would reach the point where they would no longer attract the best resources (personnel and plant equipment) to defense procurement. There are analytical problems involved in answering this question because the available profit statistics are renegotiation figures which reflect different cost bases than those established in defense contracts. Hence, the renegotiation cost bases are thought to contain from one to four per cent more costs than Department of Defense costs. $^{31}$ In addition, no collateral information has appeared at this time to verify the fact that defense contracting profit rates are discouraging the use of resources. Actually, the available information seems to indicate the reverse-there appears to be more competition for government contracts now than ever before. However, the need for higher profits on defense work is evidently a component of the new Department of Defense profit regulations.

What, then, do these new Department of Defense profit regulations provide? Essentially, they separate negotiated profit into two major and three minor components. $^{32}$ Each of these components is to be analyzed and negotiated separately with the total profit for each contract being the sum of the five. The two major components are the input of the contractor in terms of the amount and quality of effort which the contractor himself will put into the job and the assumption of cost responsibility of the contractor. In the first area of contractor input the new guidelines give high profit rates for engineering and management labor, middle rates for manufacturing labor and indirect costs, and low profit rates for subcontracted effort. In each case there is a range of profit with some judgment being required by the person negotiating the contract. In the cost responsibility area, the use of a firm fixed-price contract provides a high rate of profit, the incentive types of contract yield median rates of profit, and the CPFF contract provides almost no profit component in this area. The other factor to be considered in this area is the accuracy and closeness of the contractor's cost estimate-here too a degree of judgment will be required. The three minor components all have a relatively small effect on profit. They are the past performance of the contractor, a factor including the source of the resources used by the contractor plus any special achievement required by the contract and a special profit bonus if the item being procured was developed by the contractor at his own expense. The range of these factors is approximately as follows:

to $\$ 2$ billion per year); and on the 2ssumption that this type sales is generally more profitable than the average, may have considerable infuence in the noticeable reduction of profit rates from 1957 to 1958 . The more liberal depreciation rules have undoubtedly increased the costs of contractors and may therefore have had some effect in the profit reduction from 1962 to 1963 . However, it is very questionable whether this impact is as great as it will be in later years.

${ }^{31}$ See note 24 supra.

${ }^{82}$ The new regulations are set forth in ASPR $3-808,32$ C.F.R. $\$ 3.808$ (rg63). They are quite complex and require detailed analysis to derive a full understanding of their impact. The analysis in the text is therefore a broad summary that does not attempt to depict the specific workings of this profit policy. 


$\begin{array}{lcr} & \text { Minimum } & \text { Maximum } \\ \text { Contractor Input } & 4 \% & 9 \% \\ \text { Assumption of Cost Responsibility } & 0 & 7 \% \\ \text { Past Performance } & -2 \% & 2 \% \\ \text { Resources and Special Achievement } & -2 \% & 2 \% \\ \text { Independent Development } & \frac{0 \%}{4 \%} & \mathbf{4 \%} \\ \quad \text { Total ......................... } & 24 \%\end{array}$

The result of these new profit guidelines can be forecast to be profit rates in the range of eight to twelve per cent for development contracts using incentive contracts and of ten to fifteen per cent for manufacturing contracts of a firm fixed price basis. These ranges would appear to indicate increased profits for contractors. However, using contract types with less risk in the same situation changes the profit ranges substantially. Hence, development contracts on a CPFF basis will probably yield profit rates in the range of six to nine per cent and manufacturing contracts on an incentive basis will yield profits in the range of six to ten per cent.

The crucial problem that can be foreseen in the application of these profit guidelines is whether they will be applied without regard to the bargaining power of the parties. For instance, if the contractor feels the guidelines do not yield a sufficiently high rate of profit to justify taking the work, will the government be willing to pay more than the guidelines provide? Conversely, if the government negotiator has been purchasing from a contractor at certain profit levels, will he be willing to pay substantially higher profit rates as dictated by the new guidelines even though he knows that the contractor would perform the work for the previously acceptable profit rate? The intent of the Department of Defense appears to be to allow profit rates to increase if so dictated by the new profit guidelines. For instance, the new regulations contain the following language:

It is the policy of the Department of Defense to utilize profit to stimulate efficient contract performance. Profit generally is the basic motive of business enterprise. The government and defense contractors should be concerned with harnessing this motive to work for more effective and economical contract performance. Negotiation of very low profits, the use of historical averages, or the automatic application of a predetermined percentage to the total estimated cost of a product, does not provide the motivation to accomplish such performance. Furthermore, low average profit rates on defense contracts overall are detrimental to the public interest. Effective national defense in a free enterprise economy requires that the best industrial capabilities be attracted to defense contracts. These capabilities will be driven away from the defense market if defense contracts are characterized by low profit opportunities. Consequently, negotiations aimed merely at reducing costs by reducing profits, with no realization of the function of profit cannot be condoned. For each contract in which profit is negotiated as a separate element of the contract price, the aim of negotiation should be to employ the profit motive so as to impel effective contract performance by which overall contract costs are economically controlled. To this end, the profit objective must be fitted to the circumstances of the particular procurement, giving due weight to each of the performance, risk, and other factors set 
forth in ... [this regulation $3-808$ ]. This will result in a wider range of profits which, in many cases, will be significantly higher than previous norms. ${ }^{33}$

Another recent Department of Defense policy statement throws additional light on this problem. In a memorandum to the military services, the Assistant Secretary of Defense for Installations and Logistics directed that cost sharing not be used as a cost reduction device, i.e., that cost-sharing contracts not be negotiated in cases where the government's superior bargaining position enabled it to force such a contract on a contractor. ${ }^{\mathbf{3 4}}$ In this memorandum it is pointed out that the costsharing type contract was intended for use when a contractor would derive some substantial benefit from the contract that would compensate for the cost it provided. The memorandum pointed out further that the use of cost-sharing contracts in other situations would encourage underbidding and enable large contractors with financial resources to force smaller contractors out of the competition for such work. Hence, this is a case where the Department of Defense has specifically directed its procurement personnel not to allow contractors to reduce their profits as a bargaining device.

These recent directions from the Department of Defense indicate a major effort to change the concept of profit in the Department. This effort is directed at two objectives-the use of profit as a motivation for better performance, and the establishment of profit rates at levels which are fairer to contractors. It should be noted, however, that these policies only apply to the procurements which are subject to cost analysis and negotiation. They do not apply to price-competition type procurements. Hence, in one sense they are aimed at increasing profits in the noncompetitive part of defense procurement. ${ }^{35}$ It is difficult to determine whether this policy is

${ }^{33}$ ASPR 3-808.I(a), 32 C.F.R. $\$ 3.808-1$ (a) (I963). See also DOD Policy Paper, supra note 7. The difficulty from the point of view of the Government negotiator is that he is trained to expect some benefit for the Government in return for higher profits and the benefits that can be achieved from generally higher profits are quite remote. Hence, such benefits as increased financial ability of the contractor, greater ability to buy new capital equipment, increased ability to conduct independent research and development programs, or ability to attract superior management personnel may be advantageous to the government in the long run but they do not appear to be the type of benefits that a government negotiator normally looks to when he prices a contract. From his point of view higher profits on a contract mean only higher costs to the government immediately.

${ }^{34}$ Ass't Secretary of Defense (I \& L) and Ass't Secretary of Defense (Dept. Dir. Def. R \& E) Memorandum, Oct. 2, 1963, set forth in Air Force Procurement Circular No. 89, No. 5, I963, 6 Gov'T CoNT. REP. $\{80,127(1963)$.

${ }^{35}$ Renegotiation figures indicate the following profit rates on different types of contracts:

\begin{tabular}{lccc} 
Fiscal 1963 Filings & Renegotiable Sales & Renegotiable Profits & Percentage \\
Cost plus fixed fee & $\$ 11,052,000,000$ & $\$ 348,000,000$ & $3.15 \%$ \\
Fixed Price & $14,389,000,000$ & $309,000,000$ & $2.15 \%$ \\
Other & $5,787,000,000$ & $159,000,000$ & $4.47 \%$ \\
\cline { 2 - 2 } & $\$ 31,228,000,000$ & $\$ 916,000,000$ & $2.94 \%$
\end{tabular}

This information is included in the 1963 Renegotiation Board Report to Congress. Since this is the first time the renegotiation statisties have been broken down in terms of types of contracts, these figures cannot be compared to previous years to ascertain the trends in this area. It should be noted that the "Other" category in the statistics is made up of incentive, redeterminable and time and material contracts for the greatest part. It is also of interest that the "Fixed Price" category includes two components, 
necessary because profits in this segment of defense work are too low or whether the policy is merely a product of some other need which the Department of Defense was attempting to meet when the new profit policies were promulgated. However, the impact of the new policies will undoubtedly be quite pronounced in the next few years.

\section{III}

\section{Comparison of the Vartous Policies in the Pricing Area}

What, then, is the total pricing policy of the government as enunciated by the Department of Defense? First, obtain competition whenever possible and when competition is used do not be concerned with the profit that is earned. Second, if competition cannot be obtained scrutinize the costs closely to assure that they are estimated at a reasonable level and do not contain too many contingencies or unallowable costs. Then add to these costs a profit that gives the contractor a fair return for the job considering his effort, risk, and past performance. In addition, use the profit component as an inducement to further reduce costs during performance of the work. Does this policy stand as a coherent entity or does it contain internal conflicts?

The initial question which an overall review of the policy raises is the possibility that the competition aspect of the policy may be accomplishing the opposite result as the policies being pursued in the area of defense procurement where cost analysis and profit determinations are used. Increased competition is expected to result in lower prices-as much as twenty-five per cent lower in accordance with Department

contractors who earned a profit on all of their fixed-price contracts for the year (in the aggregate) and contractors who incurred a loss on all of their fixed-price contracts for the year (in the aggregate) as follows:

Renegotiable Sales

Fixed Price (Companies

reporting a Net Profit)

Fixed Price (Companies

reporting a Net Loss)

Total

$$
\$ 10,978,000,000
$$

$\frac{3,411,000,000}{\$ 14,389,000,000}$

Renegotiable Profits

$$
\$ 620,000,000
$$

$\frac{-311,000,000}{\$ 309,000,000}$

Percentage

$$
5.65 \%
$$$$
2.15 \%
$$

Thus, although these statisties do not represent a clean breakdown between profitable fixed-price contracts and loss fixed-price contracts, they do present a dramatic picture of the impact of loss contracts on the overall profit rates achieved in fixed-price work. In contrast, the renegotiation figures indicate that there were almost no aggregate losses incurred in the "CPFF" or "Other" categories in these figures. It should be noted that the only similar information previously made available by the Renegotiation Board gave a strikingly different picture. This information was a statistical survey of the profits of the 25 companies with the largest renegotiation refunds from I95I through I959. This information covered renegotiable sales of $\$ 25.7$ billion and reported the following profit rates on various types of contracts:

$\begin{array}{lr}\text { Type of Contract } & \text { Profit (as a percentage of sales) } \\ \text { Firm Fixed Price } & 18.3 \% \\ \text { Redeterminable Fixed Price } & 10.6 \% \\ \text { Fixed Price Incentive } & 8.8 \% \\ \text { Cost Reimbursement } & 4.9 \%\end{array}$

See Hearings Before the Special Subcommittee on Procurement Practices of the Department of Defense of the House Armed Services Committee, 86th Cong., 2d Sess. 316 (1960). 
of Defense statements. ${ }^{36}$ Thus, there is a real possibility that competition will reduce profits (although the hope seems to be that it will merely eliminate the high cost producer or the high cost production technique and hence primarily reduce costs). This possibility is especially real as competition is extended to the marginal areas such as those covered by the effort to establish second sources for complex equipment. In such cases, the second source is expected to undertake the initial manufacturing effort at a cost close to that established by the original manufacturer after substantial experience. To do this the second source may have to defer charging the full cost of necessary engineering and tooling to the contract and may have to substantially reduce his profit margins. In addition, there may well be a tendency on the part of contractors to minimize the difficulties of the job if the need for the work is sufficiently great. Of course, the cost to the procuring agency will be low but it may be at the expense of profit. Is this compatible with the policies being pursued when no competition is obtained?

Perhaps it can be argued that when competition can be obtained the working of the system will assure that eventually reasonable profits are paid with the weak companies falling by the wayside. ${ }^{37}$ Perhaps it can be argued further that in this area there are sufficient producers so that the loss of a few will not hurt the government but rather will improve the system by eliminating high cost performers. However, it is difficult to see why these arguments do not apply equally to the contractors involved in sole source or limited source procurements where cost analysis and profit determination techniques are used. In that area, too, there appears to be an abundance of companies eager to obtain defense contracts and the general opinion seems to be that many of the high cost producers work in this area. ${ }^{38}$ Hence, there would seem to be some basic lack of coordination in these two sides of pricing policy.

An even more striking problem can be seen when competition is injected in the cost-profit determination area. For instance, when incentive development contracts are initially put out to contractors for proposals, competition is the normal rule. Of course, this competition is not price competition alone-it incorporates technical and management considerations to a large degree. But the pricing element is present and often induces contractors to reduce their cost estimates in an attempt to submit a "competitive" proposal. The result may be low target costs on incentive contracts (or difficult performance goals if performance incentives are being used) with the result that the ultimate profit earned on the contract will be less than the target

${ }^{36}$ Cost Reduction REPORT, op. cit. supra note 8, at 42; DOD Policy Paper, supra note 7.

${ }^{87}$ The use of competition seems to result in lower profit-based on the assumption that most price competitive procurement results in fixed-price contracts, see note 35 supra. However, it must be realized that these figures reflect procurements made before the recent change in policy and that they may not be any indication of the profits being realized on the contracts that are being shifted to a competitive basis.

${ }^{38}$ It can also be argued that the comparison of figures on profit as a percentage of cost or sales is not a good measure of profit sufficiency in the defense business. Numerous commentators have felt that profits as a percentage of net worth was a better measure. Using this measure, defense profits are quite high. For instance, the latest Fortane profit survey indicates that in 1962 four of the top ten companies in profit on net worth were major defense contractors (\#3 Ling-Temco-Vought, 32.5\%; \#5 General Dynamics, 31.0\%; \#7 Lockheed Aircraft, 28.4\%; \#9 Magnavox, 26.5\%). 
profit. This is a technique for "buying in" on an incentive contract. The interesting facet is that at the same time that competition is having this effect on targeting under incentive contracts, the profit guidelines will increase the rate of target profit or fee on such contracts. Hence, the contractor will be able to submit more unrealistic targets and still come out of the contract with the profit which he feels necessary for the work. For example, contractors may feel that a profit rate of three per cent is perfectly acceptable on a development contract (such a rate has evidently been acceptable for a number of years) with the important consideration being the obtaining of the work. If the target profit or fee will be established at a rate of nine per cent under the weighted guidelines, the contractor can utilize the six per cent differential as a sales tool by promising targets that are difficult to attain. Of course, the proposal must be credible or the government may reject it, but there often is a relatively wide band of credibility in the development area.

This difficulty demonstrates an internal conflict within the new profit regulations. If the Department of Defense establishes higher rates of profit as standards, does this not merely give contractors a greater inducement to submit unrealistic estimates of other elements (costs or performance targets) of a procurement in an effort to sell the job? It would seem that this is a fair conclusion-especially when there was no indication of an exodus from the defense industry when profit levels were at the old rates. Hence, the new profit policies may be directly opposed to one of the major purposes of the increased use of incentive contracts-the purpose of obtaining more realistic original proposals.

Another question needs to be raised in regard to the function of incentive contracts. This type of contract is being used as the major device for giving contractors incentive to reduce costs. At the same time, however, other policies are aimed at the same objective. Two such policies are the use of performance rating systems and the inclusion of past performance as a factor in establishing the profit under the new profit policies. ${ }^{39}$ In addition, it should be realized that the major incentive operating in the government contracting area is still the desire to obtain future business. The question which arises is whether all of these other incentives do not almost completely override the operation of the profit incentives in an incentive contract. ${ }^{30 a} \mathrm{~A}$ rather convincing theoretical argument can be made that they do and recent experience in the defense business would appear to indicate that many of the incentive contracts are not being performed in a manner calculated to maximize profits. For instance, it is clear that many contractors are spending additional money to obtain improved performance even when such expenditures mean reduced profit on the immediate contract being performed. Such a decision is calculated to assure that the contractor will obtain future business-both development and manufacturing.

${ }^{\text {so }}$ See note 18 supra.

${ }^{30 a}$ A strong argument to this effect (supported by an extensive analysis of the systems procurement process) is made in F. M. Scherer, The WeApons AcQuisition Process: Economic Incentives (1963). 
If this is the case, the widespread use of incentive contracts with all of the associated risks of poor targets may not be necessary to achieve the government's pricing objectives.

Another question which should be raised is whether the policies relating to allowable costs of government work are contrary to the profit policies. In the area where prices are determined by cost analysis the trend seems to be in the direction of greater disallowances of costs which must be incurred by the contractor to perform the job. An example is the proposed limitations on bidding expenses at a time when the solicitation of more competitive proposals by the government agencies requires a contractor to incur more costs in this category. ${ }^{40}$ These costs disallowances reduce profits at the same time that the new profit guidelines increase profits. If these two policies are intended to shift some cost from the cost area to the profit areas with the commensurate advantages of relieving the government from the need of evaluating difficult cost areas as to allowability and of giving the contractors more management control over these areas, the policies fit together and make sense. However, there have been no public statements that this is the intent of the Department of Defense and there is a suspicion that the policies were not intended to have any relationship. If this is the case some thought should be given to the effect of cost disallowances on profit and motivation of a contractor toward greater efficiency in the use of resources.

This discussion leads to the final broad difficulty that is apparent in the present pricing policies. This is the underlying concept on which these policies seem to be based that the real problems in pricing of government procurement are those problems associated with the fact that such pricing is not the same as that found in commercial work. The end result of this type thinking is numerous small attempts to make government contracting function more like the commercial market place. It is suggested that this view may be a gross oversimplification of the facts. Actually, when commercial firms are dealing with products as complex as those creating the pricing difficulties for the government, they do not always rely on the workings of the market place but often utilize negotiated techniques to a greater extent than does the government in a similar situation. For instance, they do not obtain competition in many cases but choose the most capable contractor with whom to deal. In addition, in some cases cost reimbursement type contracts are used. This is not to say that sole source, cost reimbursement type procurement is good procurement but that in certain circumstances it can serve a needed role. ${ }^{41}$

For example, consider the procurement involving research and development work with a cost in the range of $\$ 100,000$ to $\$ 500,000$. At the present time, there is

10 There is a proposed change to the cost principles at ASPR 15-205.3, 32 C.F.R. $\$ 15.205-3$ (I933), providing that the engineering work in bidding costs will be treated as independent research and development costs. The effect of this change would be to make contractors bear a part of these costs in most cases (that has been the normal treatment of independent research and development costs).

"1 It might be suggested that frequently the need is not to use a different (more risky) type of contract but to bring personnel with more expertise into the buying process. Such personnel should be able to talk about and arrive at pricing solutions to the real problems present in such procurements, i.e., the technical problems which create the difficulties. 
a tendency to solicit unrestricted competition on a negotiated procurement for such work, to analyze all proposals and to award the contract to the company which has submitted the best proposal considering all factors. Such a technique is probably the closest approximation of a market place procurement technique considering the limited ability of either contractors or the government to arrive at a meaningful price under such circumstances. However, considering the proposal costs incurred by all contractors (it is not unusual to find twenty or more companies proposing to do such a job), the effort spent by the government in evaluating the proposals and selecting the contractor, and the cost of performance of the work, it is hard to believe that this is not substantially more expensive to the government than if the single or two most qualified contractors were selected for the job and all other contractors were excluded. In this type procurement, it is generally accepted that contractors' promised cost estimates have a sales flavor and are therefore lacking in real reliability. In addition, the amount of engineering talent that is wasted is enormousboth by contractors and by the government. Yet the government appears to be committed to the policy of obtaining more competition at any cost. ${ }^{42}$ In addition, following such a competition the government now intends, in many cases, to enter into performance incentive contracts based on target information which is subject to all of the distortions which such a competition can impose. Such a procedure is an invitation to contractors to play a numbers game juggling the myriad of targets, sharing arrangements and profit factors in such a way that the government thinks it is achieving its purposes, and yet attempting to maintain a minimum acceptable level of profit or at least protecting itself against a loss on the contract. ${ }^{43}$ It is suggested that this type of procurement, while it has a certain theoretical attraction, will be of no long range benefit to either the government or government contractors. Techniques of benefit in the functioning of the market place have their place in government procurement when the facts are similar but it is maintained that in many cases the government would be better advised to admit that the situation is different and not attempt to impose such techniques on procurements in that category.

\section{Conclusion}

What conclusions can be drawn from this analysis? First, it is apparent that there is no simple solution to the pricing problems faced by the Department of

12 The normal government solution is to implore contractors to reduce bidding costs; sec, for example, Jan. 12, 1962 letter from the Commander Air Force Systems Command to Air Force procurement offices (stating in part as follows in 13 : "Proposals submitted in response to our requirements need only be prepared simply and economically, providing a straightforward concise delineation of the proposing contractor's capabilities to satisfactorily perform the contract being sought. Proposals, thercfore, should be practical, legible, clear and coherent. The use of elaborate formats and binders, color where black and white would suffice, and expensive exhibits are neither required nor desired"), or to attempt to control bidding costs by threatened disallowance or partial disallowance, supra note 40 . Neither solution, of course, gets to the heart of the problem which is that the only way to reduce bidding costs substantially is for the government to accept proposals only from pre-selected qualified contractors.

${ }^{45}$ See Nash, op. cit. supra note 14, c. 3 . 
Defense or any other government agency buying complex technological products and services. There are too many contradictory factors involved. Second, the large-scale use of the CPFF contract allowing for pricing based on incurred costs by itself is not a satisfactory answer to the problem. It serves the purpose of assuring that profit rates are not excessive but it does not provide the proper motivation for control of costs. Hence, a policy which includes other devices is necessary. Third, the measures adopted by the Department of Defense in the past few years, considered separately, appear to be reasonably sound measures for achieving improvement in the overall pricing of defense contracts. The major difficulty seems to be in the interrelationships between these measures rather than the soundness of any one measure. In addition, the area in which some of these techniques are being applied is subject to question. Hence, the great need at this time is for an overall consideration of government pricing policies relating their effect to the specific areas in which they are being applied and looking toward improved internal coordination of these policies. 